\title{
RETÓRICA DE LA IMAGEN E IMÁGENES MÍTICAS
}

\author{
Rhetoric of image and mythical images
}

\author{
Henry Campos Vargas* \\ A mi ahijada María Fernanda
}

\section{RESUMEN}

El presente artículo explora las relaciones existentes entre la imagen mítica y la retórica. Con este propósito se ha partido de los principios expuesto en la Retórica de Aristóteles. Primeramente, se discute la posibilidad de esta aproximación. Seguidamente se examinan algunos aspectos relevantes de la retórica en la imagen mítica, como por ejemplo, la argumentación, las partes de la retórica, las virtudes del discurso y las funciones de la imagen.

Palabras clave: imagen, mito, función de la imagen, retórica, retórica de la imagen, ícono, argumentación, Aristóteles, Panofsky, Bauzá.

\begin{abstract}
From Aristotle's Rhetoric, this paper explores relations between mythic image and rhetoric. First we discuss the possibility of this. Then we examine some relevant aspects of the rhetoric in mythic image as argument, parts of rhetoric, virtues of discourse, functions of the image.

Key Words: image, mith, function of the image, rhetoric, rhetoric of image, icon, argument, Aristotle, Panofsky, Bauzá.
\end{abstract}

Escuela de Filología, Lingüística y Literatura. Universidad de Costa Rica. Costa Rica.

Correo electrónico: hcamposv@yahoo.es

Recepción: 2/12/2013. Aceptación: 20/6/2014. 
No cabe duda de que los mitos

(...) nos son conocidos a través de diversas fuentes -literarias, plásticas, arqueológicas, filosóficas, históricas...,- sin embargo, es la literatura la que nos proporciona mayores aportes a la hora de penetrar en ese abigarrado corpus de conceptos que conocemos con el nombre de mitología helénica, lo que es por sí misma, una circunstancia no natural ya que la literatura corresponde al dominio de la letra escrita y el mito, en cambio, en sus orígenes pertenece al terreno de la oralidad. Por lo demás, sucede con el mito griego otra circunstancia falaz: lejos de conocerlo como una realidad vital, lo conocemos fragmentariamente y a la través de la mitología (Bauzá 2004: 44).

Como se ha indicado en la cita, una de las principales fuentes para el conocimiento del mito es la literatura, sin embargo, el objeto de estas reflexiones se identifica más con las artes plásticas, ya que atenderá a expresiones tales como pinturas, esculturas, monedas, amuletos... vinculados con el mito.

Si bien en algunas ocasiones se podrá aludir a manifestaciones de los mitos griegos (cuya extensión en el mundo occidental es reconocida), en realidad se pretende considerar experiencias míticas que incluso puedan referirse a nuestros días.

\section{1. ¿Qué es la iconografía?}

¿Qué representa la fotografía de un rayo que cae sobre un templo? Es tan solo eso, una imagen. Pero si el templo es el Vaticano y la fotografía fue tomada el día en que renunció un Romano Pontífice, para muchos será una coincidencia, empero, para otros, quizá sea una "señal". Por eso, es posible distinguir dos modos básicos de comprender el mundo: a uno se le llamará visión mítica del mundo, al otro, visión racionalista del mundo. Cabe destacar que ambas formas de percepción no son excluyentes entre sí, ya que pueden tener, y tienen, numerosos puntos de contacto.

De acuerdo con la Real Academia de la Lengua Española, la primera acepción de iconografía es:
1. f. Descripción de imágenes, retratos, cuadros, estatuas o monumentos, y especialmente de los antiguos. || 2. f. Tratado descriptivo, o colección de imágenes o retratos (2001: 1244).

Se trata de una palabra compuesta por dos voces griegas: عıкஸ́v (imagen) у $\gamma \rho \alpha \varphi \eta ́$ (dibujo). De la primera deriva en español la voz ícono, la cual se ha identificado por antonomasia con el arte bizantino. En razón de esta circunstancia, se ha preferido en este trabajo emplear la palabra imagen para aludir a cualquier forma de representación material, sea en pintura, en escultura, es numismática..., aunque ocasionalmente podrá emplearse el término ícono en esta acepción amplia.

Para Panofsky, por su parte,

Iconografía es la rama de la Historia del Arte que se ocupa del contenido temático o significado de las obras de arte, en cuanto algo distinto de su forma (1979: 13).

La imagen es polivalente. Una gran pluralidad de valores le están asociados en función de su contexto: no existe una identidad de significado entre los fragmentos del cráneo de un mártir que se encontraran en un museo y los que se hallen en un templo, en una casa o en el relicario de un creyente.

Tal y como se indicó supra, para los efectos del presente trabajo, no solo se considerarán las representaciones pictóricas -independientemente del medio de soporte, como jarrones, paredes, telas...- sino esculturas, entre otros.

Sus implicaciones serán consideradas en un contexto mítico, es decir, como parte de un sistema de creencias social que considera que el mito es verdadero. De esta manera, se excluyen producciones artísticas de ambientes intelectuales y culturales como los del Renacimiento, el Romanticismo... en los que el mito fue retomado como fuente de inspiración para numerosas y valiosísimas creaciones, pero en las que el mito había sufrido una degradación en su valoración veritativa funcional.

Igualmente se excluyen del presente estudio la imágenes directamente asociados a 
experiencias o manifestaciones hierofánicas, tales como la piedra de la Kaaba para los musulmanes, la imagen de la Virgen de Guadalupe, la imagen de la Virgen de los Ángeles, restos de santos... los cuales son entendidos como productos de orden trascendente. El motivo de esta decisión reside en que la retórica se concibe como una creación eminentemente humana lo cual no excluye que estudiosos como Melanchton, Lutero o Erasmo de acuerdo con sus ideas que vinculaban la retórica con Dios se aventurarían en este sentido.

De esta manera, la imagen que representa una escena, elemento o sujeto mítico posee una intencionalidad. Dicha imagen puede relacionarse con el objeto de su representación de dos maneras lógicas fundamentales: la analogía e la identidad.

La analogía se basa en la coincidencia de elementos semejantes entre el ícono y el objeto de la representación. De esta manera, este es evocado por aquel en la mente del observador.

En la identidad, por su parte, el ícono se confunde con el objeto, lo que daría lugar a fenómenos como la idolatría y su contrario el movimiento iconoclasta. Ciertamente, al producirse la confusión ícono-objeto, el ícono pierde toda su función representativa para constituirse en ídolo.

Ha sido Mircea Eliade quien ha explicado con agudeza la configuración de ese tiempo fontal y paradigmático de los mitos y la manera como es revivido por el ritual, por la recitación de determinadas composiciones sacras o, entre otras posibilidades, por la vivencia de situaciones extraordinarias sentidas como hierofánicas por los miembros de tales comunidades. "No se trata de una conmemoración de los acontecimientos míticos, sino de su reiteración. Las personas del mito de hacen presentes, uno se hace su contemporáneo. Esto implica también que no se vive ya en el tiempo cronológico, sino en el Tiempo primordial, el Tiempo en el que el acontecimiento tuvo lugar por primera vez" (Mircea Eliade, citado por Bauzá 2004: 42).

La representación icónica, como todo proceso retórico, implica una serie de elecciones que pueden examinarse desde este marco teórico.

Las imágenes poseen sentido y referencia. Su sentido viene dado por la interpretación de su significado.
Por su parte, la referencia, que no es del todo ajena al sentido, consiste ya en el objeto físico o persona representados, ya en la escena descrita. De esta manera, un crucifijo cristiano tiene como referente a Cristo muriendo en la Cruz; una reproducción de la imagen de La Negrita tiene como referente la muñequita de piedra encontrada por quien fue llamada Juana Pereira; un mural sobre la multiplicación de los panes y los peces tiene como objeto ese evento bíblico.

\section{2. ¿Qué es la retórica?}

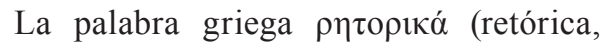
oratoria) no es de gran ayuda para determinar el significado etimológico de la palabra. La primera acepción nos hace incurrir en una petición de principio al definir este sintagma con su equivalente morfológico en español. La segunda, en cambio, tiene la virtud de definirla como oratoria. En realidad, el germen de la polisemia que a lo largo de la historia ha mostrado el término retórica se encuentra en la amplitud semántica del significante léxico del que procede.

La raíz indoeuropea wer- (hablar) dio origen en latín a la voz verbum (palabra) y en griego al verbo eıрo (decir), cuyo adjetivo verbal es $\rho \eta \tau o ́ \varsigma$ (dicho, expresado, razonable, racional). La familia léxica de este último significante es amplia y prolija: forman parte de ella sintagmas

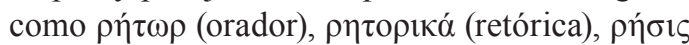
(discurso) y términos con directa semántica

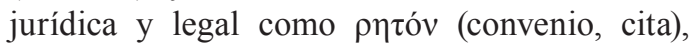

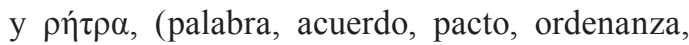
precepto, máxima, proverbio e, incluso, derecho de hablar, además de ser el nombre de ciertos pilotes levantados a la vera de los caminos de algunas ciudades griegas en los que se consignaban y publicaban los preceptos de la ley). Palabra, razón y derecho son así tres ejes semánticos fundamentales y constantes para comprender qué es la retórica.

Etimológicamente retórica es el estudio de la palabra, pero es un estudio sobre la eficacia de la palabra: sus condiciones, contexto, sujetos. 
La retórica es una teoría de la enunciación, a partir de esta noción han sido construidos los diversos y prolijos sistemas retóricos. Esta idea es común a la mayor parte de definiciones del concepto y respeta el origen etimológico del término (retórica como oratoria). Es una teoría de la enunciación que involucra aspectos estéticos y de eficacia.

\section{Limitaciones para esta aproximación}

Desde un punto de vista aristotélico existe un escollo significativo para realizar este tipo de análisis, es decir, asociar la retórica con las representaciones plásticas: los objetos de esta naturaleza constituyen pruebas no técnicas, es decir, consisten en pruebas ajenas al arte.

En efecto, Aristóteles distingue dos tipos de prueba, las técnicas, o propias del arte, y las no técnicas, o ajenas al arte:

En cuanto a las pruebas por persuasión unas
son ajenas al arte (písteis átechnoi) y otras son
propias del arte (písteis éntechnoi). Llamo ajenas
al arte a cuantas no se obtienen por nosotros, sino
que existían de antemano, como los testigos, las
confesiones bajo suplicio, los documentos y otras
semejantes; y propias del arte, las que pueden
prepararse con método por nosotros mismos, de
modo que las primeras hay que utilizarlas y las
segundas inventarlas (1990: 174, 1355b 35-40).

De lo anterior se colige que una imagen usada como prueba, en un contexto oratorio, deviene en prueba ajena al arte, o no técnica, ya que no es producida por el discurso.

Sin embargo, lo cierto es que tanto las llamadas pruebas no técnicas como las propiamente tales exigen un tratamiento apropiado por parte de todo orador. En este sentido, en un proceso judicial, por ejemplo, un manejo hábil y preciso de un interrogatorio, puede alcanzar directa e inmediatamente el convencimiento del auditorio y del juez, simplificando sobremanera la ulterior etapa de conclusiones (que quizá para el pensador de Estagira sería propiamente el objeto de la retórica).
Otra aparente limitante para el presente examen parece ser el carácter no verbal de las imágenes. Empero, es posible distinguir al menos dos grandes grupos de representaciones: las que tienen propiedades narrativas $y$ las que no. En las primeras se integran las representaciones de escenas, lo que permite descubrir una especie de texto, de narración mítica. Por ejemplo, en un jarrón griego bien podría encontrarse representada la escena en la que Odiseo junto con sus compañeros penetra el ojo del Cíclope que los mantenía cautivos. La acción es completamente comprensible para un observador, a quien le trae a la mente el mito del nostos de este héroe.

También puede incluirse en este grupo las secuencias o series de imágenes concatenadas que se encuentran en numerosas basílicas europeas en las que se describen las historias de los patriarcas, de Jesús o de santos.

Otras obras, en cambio, pueden limitarse a objetos de orden mítico - coronas de personajes míticos, espadas, escudos...- o personajes aislados, en particular, de divinidades y héroes. Por ejemplo, la imagen de Atenea en algún objeto. En estos, los rasgos narrativos se minimizan; no obstante, es posible efectuar una especie de lectura de la imagen: en el ejemplo, cuáles son las propiedades asignadas a Atenea, así como los símbolos que la acompañan (por ejemplo, en algunas representaciones, una diosa alada).

Una última limitación se encuentra en el carácter argumentativo del proceso retórico, una de sus propiedades principales. De acuerdo con Aristóteles la retórica es

(...) la facultad de teorizar lo que es adecuado para convencer. Esta no es ciertamente tarea de ningún otro arte, puesto que cada uno de los otros versa sobre la enseñanza y persuasión concernientes a su materia propia; como, por ejemplo, la medicina sobre la salud y lo que causa enfermedad, la geometría sobre las alteraciones que afectan a las magnitudes, la aritmética sobre los números y lo mismo las demás artes y ciencias. La retórica, sin embargo, parece que puede establecer teóricamente lo que es convincente en -por así decirlo- cualquier caso que se proponga, razón por la cual afirmamos que lo que a ella concierne como arte no se aplica sobre ningún género específico (1990: 173-174, 1355b25-39). 
Si esto es así, ¿cómo encontrar este rasgo en las representaciones? Una posible solución se ofrecerá más adelante. Por el momento conviene dirigir la mirada a la propia retórica, la cual parece ofrecer una solución al problema imagenarte retórica: desde la antigüedad una de sus partes, la memoria, integra de manera operativa esta relación.

Aunque casi todos los tratadistas de retórica mencionan la importancia de la memoria (la cual, por cierto, está ausente en Aristóteles), la Retórica a Herenio ofrece el tratamiento más antiguo que se conserva, al consagrarle una sección detallada. Se cree que las teorías expuestas en dicha obra proceden de Hermágoras o de Carmadas y Metrodos, maestros de Antonio (el propio texto reconoce la existencia de obras en este sentido, al respecto puede consultarse 220, III, 38).

Thesaurus inventorum (tesoro de la invención retórica) y custos rhetoricae (custodio de la retórica, 204, III, 28) son dos de los epítetos con los que se califica a la memoria en dicha obra, la cual, para su autor, constituye un verdadero arte. Luego de reconocerse la existencia de una memoria natural y otra artificial, se establece que esta última consta de dos recursos: los loci (lugares, entornos) y las imagines (imágenes, 208, III, 29).

Locos appellamus eos qui breviter, perfecte, insignite aut natura aut manu sunt absoluti, ut eos facile naturali memoria conprehendere et amplecti queamus: ut aedes, intercolumnium, angulum, fornicem, et alia quae his similia sunt.

Imagines sunt formae quaedam et notae et simulacra eius rei quam meminisse volumus; quod genus equi, leonis, aquilae memoriam si volemus habere, magines eorum locis certis conlocare oportebit (208, III, 29-30).

Llamamos lugares a los que de manera concisa, perfecta y clara, ya sea por la naturaleza o por la mano del hombre, han sido puestos para que fácilmente los podamos explicar y asociar a la memoria natural: como una casa, un intercolumnio, una sala, una bóveda y otros semejantes. Las imágenes son ciertas formas, símbolos $\mathrm{y}$ representaciones de la cosa que queremos recordar, por lo que si deseamos traer a la memoria un tipo de caballo, de león o de águila convendrá ubicar imágenes de ellos en lugares apropiados (la traducción es del autor).

El texto mismo ofrece algunos ejemplos de cómo se conjugan los loci y las imagines:

Rei totius memoriam saepe una nota et imagine simplici conprehendimus; hoc modo, ut si accusator dixerit ab reo hominem veneno necatum et hereditatis causa factum arguerit et eius rei multos dixerit testes et conscios esse. Si hoc primum, ut ad defendendum nobis expeditum sit, meminisse volemus, in primo loco rei totius imaginem conformabimus; aegrotum in lecto cubantem faciemus ipsum ilium de quo agetur, si formam eius detinebimus; si eum non agnoverimus, at aliquem aegrotum non de minimo loco sumemus, ut cito in mentem venire possit. Et reum ad lectum eius adstituemus, dextera poculum, sinistra tabulas, medico testiculos arietinos tenentem. Hoc modo et testium et hereditatis et veneno necati memoriam habere poterimus (214, III, 33). A menudo, a un solo símbolo y una sencilla imagen
asociamos el recuerdo de un asunto completo, a
la manera que un acusador podría decir que un
hombre fue asesinado por el reo mediante un veneno
y arguyera que lo hizo por una herencia y que hay
muchos testigos y cómplices. Si queremos recordar
esto de primero, para que nos sea más expedita la
defensa, en primer lugar dispondremos la imagen
de todo el caso: pondremos a un hombre enfermo
recostado en la cama, precisamente a aquel del
cual trata el proceso, eso si tenemos una imagen de
él; si no lo conociéramos, tomaremos a algún otro
enfermo que no sea de un status inferior para que
rápidamente nos pueda venir a la mente. Pondremos
de pie al reo junto a su lecho, en su mano derecha
una copa, en la izquierda unas tablas, y en el dedo
anular unos testículos de carnero colgando. De esta
manera, podremos recordar a los testigos, la herencia
y la muerte por el veneno (la traducción es del autor).

Se trata de una verdadera ilustración, de un cuadro mental ideado como recurso mnemotécnico. Salta a la vista que se trata de algo más que lenguaje gestual, algo que tiene lugar, por ejemplo, en las celebraciones litúrgicas cristianas, durante las cuales la postura del cuerpo está asociada a determinados significados: el estar de pie es símbolo de encontrarse preparado para la acción, el encontrarse sentado, por su parte, demuestra atención, mientras que el hincarse indica adoración.

El texto de la Retórica a Herenio pone de manifiesto la necesidad de que exista un código 
para la relectura (es decir, la conversión de la imagen en el discurso inicial) que permitiría su interpretación. Dicho código es arbitrario y parece poseer ciertos rasgos privados, empero, muchos de los símbolos que lo integran forman parte de la cultura general del orador (por ejemplo, la relación de las voces latinas testes (testigos) y testiculus (testículos)).

En el siguiente ejemplo el autor de la Retórica a Herenio aplica este procedimiento a la poesía:

Cum verborum similitudines imaginibus exprimere volemus, plus negotii suscipiemus et magis ingenium nostrum exercebimus. Id nos hoc modo

facere oportebit:

Iam domum itionem reges Atridae parant.

Hunc versum meminisse si volemus, conveniet primo in loco constituere manus ad caelum tollentem Domitium cum a Regibus Marciis loris caedatur hoc erit "Iam domum itionem reges"; in altero loco Aesopum et Cimbrum subornari ut ad Iphigeniam in Agamemnonem et Menelaum -hoc erit "Atridae parant". Hoc modo omnia verba erunt expressa (216, III, 34).

Cuando queramos expresar con imágenes la semejanza de las palabras, mayor esfuerzo nos tomará y ejercitaremos más nuestro ingenio. Convendrá que lo hagamos de esta manera:

"Ya su regreso a la patria preparan los reyes átridas".

Si quisiéramos memorizar este verso, en primer lugar conviene poner a Domicio con las manos elevadas al cielo cuando era azotado con correas por los reyes Marcios; esto representará "ya su regreso a la patria los reyes". En otro lugar, Esopo y Cimbro serán dispuestos como Agamenón y Menelao para representar Ifigenia; esto será "átridas preparan". De este modo, todas las palabras habrán sido representadas (la traducción es del autor).

Tal y como se aprecia, el anónimo autor de la obra recomienda el empleo de imágenes como recurso mnemotécnico, pues la memoria sienta sus bases en la imagen. Merced a un código que el orador desarrollará ad hoc, cada elemento de la composición de la imagen habrá de estar asociado a una parte del discurso. En este sentido, debido al momento en que tiene lugar, el discurso genera la imagen $y$, posteriormente, la imagen permite reconstruir el discurso. De esta forma, este breve tratado logra una síntesis dialéctica entre la imagen y el texto, en la que un elemento nutre al otro y viceversa.

Así puede apreciarse que la propia retórica ha destruido la aparente oposición entre texto e imagen.

Esta solución era plausible, dado que en la propia Poética Aristóteles establecía este nexo entre palabra e imagen:

Pues, así como algunos con colores y figuras imitan muchas cosas reproduciendo su imagen (unos por arte y otros por costumbre), y otros mediante la voz, así también, entre las artes dichas, todas hacen la imitación con el ritmo, el lenguaje o la armonía (1992: 127-128, 1447a19-22).

También en su Retórica, avanzada la exposición del libro III, retoma este vínculo al expresar:

Así, pues, la expresión propia de la oratoria política es enteramente semejante a una pintura en perspectiva, pues cuanto mayor es la muchedumbre, más lejos hay que poner la vista; y, por eso, las exactitudes son superfluas y hasta aparecen como defectos en una y otra. En cambio, la <expresión> propia de la oratoria judicial es más exacta (1999: 553, 1414a8-12).

De esta manera, tanto la literatura como las artes plásticas serían formas de imitación para el pensador de Estagira.

En un plano considerablemente distinto, a saber, el de la crítica retórica se han abordado problemas semejantes con la siguiente solución:

Si todo lo que se refiere a la experiencia humana está construido en forma lingüística, entonces la gama de textos susceptibles de análisis retórico se amplía hasta incluir manifestaciones no discursivas como el Monumento a los Veteranos de la Guerra de Vietnam en la ciudad de Washington, DC (Blair et al., 1991) y los museos de los pioneros de la colonización israelí (Katriel, 1994) (Gill y Whedbee 2003: 236-237).

Para las artes plásticas, por su parte, Enrique Lafuente Ferrari, en la introducción a Estudios sobre iconología, de Erwin Panofsky, destaca: 
En una obra de arte, escribe Panofsky, la forma no puede separarse del contenido; la distribución del color y las líneas, la luz y la sombra, los volúmenes y los planos, por delicados que sean como espectáculo visual, deben entenderse también como algo que comporta un significado que sobrepasa lo visual (1979: XV).

A continuación se abordarán distintas soluciones a estos problemas, a la vez que se proponen los posibles matices retóricos de las imágenes.

\section{Imagen y géneros de la retórica}

\section{De acuerdo con La Retórica de Aristóteles}

Tres son en número las especies de la retórica, dado que otras tantas son las clases de oyentes de discursos que existen. Porque el discurso consta de tres componentes: el que habla, aquello de lo que habla y aquel a quien habla; pero el fin se refiere a este último, quiero decir, al oyente. Ahora bien, el oyente es, por fuerza, o un espectador o uno que juzga; y, en este último caso, o uno que juzga sobre cosas pasadas o sobre cosas futuras. Hay, en efecto, quien juzga sobre lo futuro, como, por ejemplo, un miembro de una asamblea, y quien juzga sobre sucesos pasados, como hace el juez; el espectador, por su parte, juzga sobre la capacidad del orador. De modo que es preciso que existan tres géneros de discursos retóricos: el deliberativo, el judicial y el epidíctico (1990: 193-194, 1358a36-1358b8).

En esta obra, el pensador de Estagira emplea indistintamente las voces génos y ê̂dos para referirse a esta tipología. Ahora bien, cada uno de los tipos de discurso posee características particulares:

Lo propio de la deliberación es el consejo o la disuasión; pues una de esas dos cosas es lo que hacen siempre, tanto los que aconsejan en asuntos privados, como los que hablan ante el pueblo a propósito del interés común. Lo propio del proceso judicial es la acusación o la defensa, dado que los que pleitean forzosamente deben hacer una de estas cosas. Y lo propio, en fin, del discurso epidíctico es el elogio y la censura (1990: 194, 1358b9-14).

$\mathrm{Su}$ fin es distinto, pues así como lo conveniente y lo perjudicial son el objeto del discurso deliberativo; lo justo y lo injusto, del judicial; y lo bello y lo vergonzoso del epidíctico.
Con base en lo anterior, a primera vista, parece ser que el discurso epidíctico es el más próximo al tema de las imágenes, dada la proximidad que tiene con los valores estéticos, en particular, lo bello y lo feo, lo bueno y lo malo (en este sentido Aristóteles 1999: 240, I.1366a25-27).

Sin embargo, discursos de carácter deliberativo y judicial pueden estar asociados a distintos tipos de imágenes.

Tal y como se indicó supra, para Aristóteles el género deliberativo trata sobre lo conveniente y lo perjudicial, valores que pueden ser desarrollados en numerosos ámbitos del pensamiento mítico a través de imágenes. De esta manera, así como para exaltar la conveniencia de la guerra puede ofrecerse la representación de un héroe mítico en todo su esplendor -con el propósito de motivar al conglomerado social a seguir su ejemplo-, para respaldar la tesis contraria podrían mostrarse en una pintura los mayores horrores de la guerra, y así disuadir de su búsqueda. En este sentido el recurso a las figuras de santos y ángeles gozosos en el cielo en el cristianismo bien puede representar un medio para inducir la apetencia por la visión beatífica; mientras que las escalofriantes y aterradoras escenas del infierno, con sus llamas, demonios amenazantes y rostros desesperados de las almas en pena, procurarían disuadir al creyente del camino del pecado.

Un examen similar puede establecerse respecto del género judicial, cuyo fin es lo justo y lo injusto. Viene a la memoria la imagen de Jesús al expulsar a los mercaderes del Templo de Jerusalén, una conducta que a través de los siglos ha sido considerada justa. En igual sentido, están relacionadas con el tema de la Justicia Divina numerosas obras en las que aparece representada la escena del Juicio Final: en lo alto, hacia el centro, la Santísima Trinidad junto a todos los santos, mientras que en la parte inferior se distingue a los condenados sufriendo los tormentos del infierno. Nociones como justicia social se ven representados en numerosos cuadros de pintores con esta preocupación, la justicia conmutativa, a su vez, puede ilustrarse perfectamente al representar una transacción 
comercial en la que se aprecia el pago del precio y la recepción del objeto.

De esta manera, se ilustra con claridad cómo los tres principales géneros retóricos pueden verse relacionados en una imagen.

Durante la Reforma Protestante Melanchton propuso la existencia de un cuarto género, el didascálico, vinculado con la enseñanza. A este respecto, la historia del arte comprueba que muchas obras de carácter religioso fueron elaboradas con el propósito de instruir y adoctrinar a las grandes masas populares, con lo que este mismo género no se vería excluido del campo de la imagen.

Ahora bien, en la retórica griega se plantearon numerosas retóricas especiales, tal y como ejemplifican las obras de Dioniso Halicarnaso y Menandro el Rétor. Así, por ejemplo, se propone la existencia de una retórica para la fábula, otra para los himnos, también la hay para los epitafios, los epitalamios, etcétera. Correlativamente, podría desarrollarse una retórica iconográfica para temas específicos de esta o cualquiera otra índole.

\section{Virtudes del discurso e imagen}

Siguiendo una larga tradición retórica que Quintiliano refiere a Isócrates, pero que puede encontrarse en rétores anteriores, el De inventione de Cicerón señala:

Creo que es ahora el momento de hablar de la narración que consiste en la exposición de la causa. Tres son los requisitos que debe tener: ser breve, clara y verosimil (1997: 122; I, 28).

Estos tres desiderata se conocen como las tres cualidades (virtutes) necesarias para la narratio, que corresponden a los términos latinos brevis, breve; dilucida/aperta/perspicua, clara; y verisimilis/ probabilis, verosímil (véase Mortara :76).

Para Cicerón:

Será breve si la hacemos comenzar en el punto preciso, es decir, si no nos remontamos a los acontecimientos más lejanos; si cuando basta señalar los aspectos generales no mencionamos demasiados detalles, pues a veces es suficiente enunciar el resultado sin narrar cómo se produjo; si no prolongamos la narración más de lo necesario y nos abstenemos de cualquier digresión; si nos expresamos de forma que lo dicho se entienda algo que hemos callado; si pasamos por alto tanto lo que nos perjudica como lo que ni nos perjudica ni nos beneficia; si no repetimos las cosas más de una vez ni insistimos en lo que acabamos de decir (ibid: 122-123; I, 28).

Por su parte,

La narración será clara si presentamos los acontecimientos en el orden en que sucedieron; si mantenemos el orden cronológico de los hechos de manera que se presenten tal como ocurrieron o como creemos que pudieron ocurrir. A este respecto deberemos tener especial cuidado en evitar el desorden y la confusión, no saltar de un tema a otro, no remontarnos a los hechos más lejanos ni llegar hasta los últimos y no omitir nada de lo que convenga a la causa (ibid: 123, I, 29).

Por último, la verosimilitud se consigue

(...) si en ella aparecen las características habituales de la vida real; si se respeta el rango propio de los personajes, se explican las causas de los acontecimientos, se señala que aparentemente hubo ocasión para cometer los hechos y se muestra que las circunstancias eran favorables, el tiempo suficiente y el lugar oportuno para los hechos que se narran, si los hechos se ajustan a la índole de los participantes, la opinión pública y los sentimientos de los oyentes (ibid: 124, I, 29).

Estas tres virtudes se extienden a la representación icónica. La brevedad, por las limitaciones del espacio, tiende a cumplirse ya de por sí. No parece que se vea menoscabada por los numerosos detalles que los grandes artistas suelen incorporar, ya que la brevedad se refiere a la narración que equivaldría a la escena.

La claridad de la imagen exige que se identifiquen los personajes, las acciones y el contexto, de manera que pueda ser interpretada adecuadamente su significado y mensaje.

$\mathrm{La}$ verosimilitud es la que tiene implicaciones de mayor trascendencia en este examen. Ciertamente, dado que la imagen compromete al auditorio en una experiencia, lo hace testigo, pese a sus limitaciones simbólicas, del evento mítico acaecido illo tempore (en un momento anterior, en la mayoría de los casos, muy lejano). Al coincidir con la imagen mental heredada merced a la transmisión oral 
o escrita del mito, confirma el concepto. Es una experiencia semejante a la vivida por los fanáticos de series como Harry Potter o El Señor de los Anillos al ver sus obras favoritas llevadas a la pantalla: aquello que vivieron a través de la lectura, llegan a captarlo visualmente.

La representación plástica goza de cierto margen o intervalo de tolerancia para la libertad de su hacedor, empero, ha de seguir al mito pues, de lo contrario, rompería el beneficio de la experiencia estética, la cual abruptamente podría tornarse en racional a través de una crítica como: eso no ocurrió así. Tal sería el caso de una pintura en la que el Cíclope devorara a Odiseo, ya que sabemos que eso, de acuerdo con el mito, no habría ocurrido.

Menandro el Rétor se refiere a este problema como inconsistencia en la composición hímnica, cuyo objeto de fondo es el mito:

\footnotetext{
Hay que tener cuidados primero de inventar no de manera incongruente, sino con coherencia; y eso se puede conseguir, si la invención se configura a partir de ellos y no queda desligada; después, de no hacer la invención con mal gusto, sino de manera atractiva y decorosa, como lo de las Musas, hijas de la Memoria, o cualquier cosa así $-\mathrm{y}$ es que algunas incluso son desagradables de oír, como lo de que Atenea salió de la cabeza de Zeus; pues eso no es correcto, a no ser que se haya dicho mediante alegoría y con relación a alguna otra cosa; de otra manera, se hace una invención de mal gusto -; después de basar las pruebas de lo que inventemos en algo verdadero, como nosotros hemos hecho, y con frecuencia Homero. Además, hay que procurar que los himnos ficticios sean coherentes consigo mismos y no conlleven contradicciones o discrepancias, como en el mito aquel en que Zeus nació antes que todos los seres y es padre de toda divinidad, y se casó con Temis, que era antaño mujer de Crono. Pues si era anterior a todo, también anterior a Temis, pero si Temis era anterior a Zeus, no sería él anterior a todo (1996: 105-106, 341.19-342.4).
}

Esta cita ilustra sobremanera el requerimiento de consistencia en la narración mítica. Aunque parece ir en contra de la libertad creativa del artista, muestra de manera particular cómo pueden establecerse puntos de tensión entre el texto mítico y una imagen.

\section{Las partes de la retórica}

A la retórica de la imagen es posible asignarle los tradicionales cinco partes de la oratoria, identificadas mediante voces latinas: a) inventio, b) dispositio, c) elocutio (stylum), d) memoria; y e) pronuntiatio (actio), las cuales, con Cicerón, pueden definirse así:

La invención consiste en la búsqueda de argumentos verdaderos o verosímiles que hagan creíble nuestra causa; la disposición sirve para ordenar adecuadamente los argumentos hallados; el estilo adapta las palabras apropiadas a los argumentos de la invención; la memoria consiste en retener firmemente las ideas y palabras. La representación es el control de la voz y del cuerpo de manera acorde con el valor de las ideas y palabras ( 1997: I, 9; 97).

Por la naturaleza particular de las artes plásticas, la elocutio y la pronuntiatio parecen reunirse y confundirse en un solo momento. En efecto, lo que sería la escritura del discurso y su posterior realización no parecen poder separarse en ellas.

Ahora bien, las distintas partes de la retórica tienen lugar en el proceso de producción, de generación de la imagen, de la siguiente manera:

a) Una vez seleccionado un mito, se han de buscar los símbolos e imágenes que se consideren apropiados para expresarlo desde la perspectiva del autor.

b) Se ha de definir el orden y disposición en el espacio de los elementos que integran la composición.

c) Han de identificarse los símbolos, colores, elementos apropiados... al objetivo narrativo de la imagen, las emociones y su función argumentativa. Conviene consultar cómo otros han recreado una misma escena o personaje.

d) Respecto del artista, se servirá de bocetos, borradores y numerosos recursos propios de su técnica. En cuanto al auditorio, apelará a los medios que logren suscitar en el observador el mayor cúmulo de relaciones. 
e) La realización de la obra debe procurar el mayor impacto en cada una de las funciones que cumple la imagen, tal y como se verá infra.

\section{Las pruebas aristotélicas y la imagen}

Las pruebas propiamente artísticas son el ethos, el pathos y el logos. Estas dos últimas son las que están mayormente comprometidas en las representaciones iconográficas.

Por su naturaleza, la imagen icónica suscita una experiencia estética, la cual involucra el pathos, las emociones y sentimientos del espectador. Empero, la obra de corte mítico puede ir más allá.

Ciertamente, puede haber un efecto didascálico, esto es, educativo, al transmitir fragmentos y momentos del mito. En el ambiente cristiano, es semejante a las hermosas reproducciones de pasajes y escenas bíblicos en las grandes catedrales de Europa, con el propósito de formar e ilustrar a las masas analfabetas sobre la historia de los patriarcas, de Jesús, los hechos de los apóstoles...

Igualmente, el ícono puede facilitar la comprensión del mito, así como del misterio, por ejemplo, en la representación de la Santísima Trinidad, en la que convergen las tres Personas Divinas en un solo momento integrador, pese a las dificultades cuya comprensión genera.

Pathos y logos se integran en la experiencia: la imagen confirma, verifica el sistema de creencias: lo que solo se conocía merced al $\operatorname{logos}$, la experiencia sensorial lo ratifica.

También puede hablarse de un efecto transmisor, como se ha visto.

En el plano argumentativo el exemplum (argumento y figura) desempeña un papel crucial: la imagen ejemplifica la creencia.

Estos principios de argumentación ya figuraban cuando Aristóteles se refiere al género epidíctico en relación con el auditorio:

(...) el espectador, por su parte, juzga sobre la capacidad del orador (1990: 193, 1358b7).
De manera semejante, al expresarse sobre el fin de este género, expresa:

Por último, para los que elogian o censuran, $<$ el fin es $>$ lo bello y lo vergonzoso, y estos igualmente superponen otros razonamientos accesorios (1990: 195, 1358b28-29).

\section{Niveles textuales respecto de la imagen}

Es posible distinguir varios niveles textuales en las representaciones icónicas. En primer lugar, deben ubicarse las inscripciones que se encuentran en diversos íconos. Se trata de un primer elemento textual ejemplificado en los crucifijos en los que aparece INRI, en imágenes de Jesucristo con $A$ y $\Omega$.

En las imágenes publicitarias Barthes señala que tales textos cumplen una primera función, que el llama función denominativa o de anclaje (1977: 42): dentro del cúmulo de significados e interpretaciones asociados a una imagen, este tipo de textos permite restringir, direccionar e controlar las lecturas asociadas. De esta manera, un texto como La ascensión de Jesús a los cielos, permite al observador de una pintura, por ejemplo, identificar que el cuadro trata de uno de los eventos de la vida de Jesús. Así no se confundirá con la ascensión de Mahoma a los cielos o con el carro de fuego que arrebató a Elías, en igual sentido, tampoco se asociará con uno de los momentos de su transfiguración.

Esta función de anclaje también es cumplida por el narrador, especialista en el campo o no, que explica y direcciona la comprensión de las imágenes mostradas en un video de naturaleza mítica.

Una segunda función planteada por Barthes es la de relevo o diégesis (1977: 43), la cual no se presenta en todo tipo de imágenes, sino en caricaturas o historietas, que también se presentan en el ámbito de la representación mítica. Aquí la relación entre texto e imagen es complementaria, pues es la historia, la diégesis, la narración el nivel superior en el que se obtiene la unidad del mensaje. 
Una variante interesante en la mitografía no religiosa es la flor del jacinto, de la cual se dice que tiene dibujadas las letras $A I A I$.

Por otro lado, las imágenes suscitan, generan, distintos tipos de textos. Los hay meramente descriptivos, en los que se especifican los colores, formas, posición de los elementos, integración de la composición. Los hay también hermenéuticos, en los que se interpreta la imagen y sus significados.

El siguiente senario yámbico de Catulo muestra cómo una imagen puede generar un texto literario:

\section{IV}

Phaselus ille, quem uidetis, hospites, Ait fuisse nauium celerrimus,

Neque ullius natantis impetum trabis

Nequisse praeterire, siue palmulis Opus foret uolare siue linteo. Et hoc negat minacis Adriatici Negare litus insulasue Cycladas Rhodumque nobilem horridamque Thraciam Propontida trucemue Ponticum sinum, Vbi iste post phaselus antea fuit Comata silua; nam Cytorio in iugo

Loquente saepe sibilum edidit coma. Amastri Pontica et Cytore buxifer, Tibi haec fuisse et esse cognitissima Ait phaselus; ultima ex origine Tuo stetisse dicit in cacumine Tuo imbuisse palmulas in aequore Et inde tot per impotentia freta Erum tulisse, laeua siue dextera Vocaret aura, siue utrumque Iuppiter Simul secundus incidisset in pedem; Neque ulla tota litoralibus diis Sibi esse facta, cum ueniret a marei Nouissime hunc ad usque limpidum lacum.

Sed haec prius fuere; nunc recondita Senet quiete seque dedicat tibi, Gemelle Castor et gemelle Castoris.

El barquito aquel, que miráis viajeros, dice haber sido de las naves la más veloz, y no el impulso de algún flotante madero, haber podido aventajar, ya con sus remos $\mathrm{o}$, si fuera preciso volar, con su vela.
Y niega que esto, del amenazador Adriático, niegue el litoral, y las islas Cícladas, la noble Rodas y la hórridaTracia y, en el Propóntide, el feroz sinuoso Póntico, en donde éste -el después barquito-, antes hubo frondosa selva; pues en la Citoria eloquente cima a menudo un silbido profirió el dosel.

A la Amastris Póntica y al Citoro cargado de boj, que esto haberos sido y ser conocidísimo, dice el barquito, por último, desde el origen tuyo, haber permanecido, dice, y, en los extremos tuyos, haber estrenado sus remos con agua, y desde allí por tantos mares con su impotencia a su dueño haber llevado, ya a diestra y siniestra llamaba a la brisa, ya a que Júpiter al punto favorable cayera en pie.

Y nada en absoluto a los dioses de los litorales de sí consagró cuando hubo venido desde el mar novísimo a este límpido lago.

Mas estas cosas fueron antes, ahora, en recóndito, está viejo, y en silencio se te dedica,

Gemelo Cástor y a ti, Gemelo de Cástor (la traducción es del autor).

Esta bellísima composición, al decir de los expertos, habría sido preparada en atención a una pintura de dicho barco. Su contemplación provocaría este tipo de texto.

Es patente que las imágenes suscitan distintos tipos de discursos. Se encuentran diversas écfrasis literarias antiguas de objetos asociados a temas míticos: en la Ilíada, por ejemplo, la de la copa de Néstor en el canto XI, verso 632, y la del escudo de Aquiles, canto XVIII, 468 y siguientes; de esta última considérese esta breve cita:

Cinco capas tenía el escudo, justamente, en sí, y sobre él, con expertos sentidos labraba mil relieves. Y dispuso en él

la tierra y el cielo y el mar, y el sol infatigable, la luna llena y todas las estrellas de las constelaciones de las que esté el cielo coronado, las Pléyades, Híades y la fuerza 
de Orión y la Osa y aquella

a la que Carro asimismo llaman

de sobrenombre, y en el mismo sitio

gira, y mira, aprensiva, a Orión,

y es la única que no participa de los baños

de Océano (Homero 1995: 776, 482-489).

Hesíodo, por su parte, en El Escudo detalla con gran preciosismo los motivos de aquel instrumento de batalla:

Allí estaba el hijo de Dánae, de hermosa cabellera, el jinete Perseo, ni rozando el escudo con sus pies ni lejos de él, gran obra digna de observar, pues en ningún sitio se apoyaba. Así, en efecto, lo labró con sus manos el famoso cojo de oro; en sus pies tenía las aladas sandalias; en sus hombros una nielada espada pendía de un tahalí de bronce; aquél, como un pensamiento volaba y toda la parte superior de su espalda tenía la cabeza de un terrible monstruo, la Gorgona; lo envolvía una alforja de plata, admirable de ver; brillantes franjas de oro flotaban; en torno a sus sienes el terrible casco del soberano Hades, con la terrible oscuridad de la noche (2000: 127-128, 216-228).

Ya en Roma Virgilio dedica pasajes de la Eneida a la descripción del escudo de Eneas y el cinturón (tahalí) de Talante; mientras que Catulo narra con gran precisión las imágenes que se encontraban en el tapiz regalado a los novios en el epitalamio de Tetis y Peleo (LXIV, 43-164). Se ha llamado a tales composiciones écfrasis literarias por cuanto sus autores no tuvieron físicamente a la vista el objeto de sus obras, se trata de una visión imaginativa.

Es claro que hay códigos subyacentes a la composición iconográfica. Muchos de estos códigos tienen su origen en la experiencia humana general (por ejemplo, un animal que se encuentra en el centro de varias figuras humanas que sostienen palos se asocia con facilidad a una cacería), otros, con factores culturales específicos (piénsese en la imagen de un hombre que sostiene en lo alto con sus dedos un cuerpo circular, que en la cristiandad correspondería a la consagración de la eucaristía) o a códigos artísticos (como sería el caso de asociar las palmeras con imágenes eróticas, en particular, las largas piernas de una mujer).

Distinto es el caso de Calímaco, quien en varios de sus Aitía se refiere a estatuas como la de Diana de Léucade (1980:153, 31b y ss.), la de Hera en Samos (ibid: 183, 101) y la del Apolo de Delos (ibid: 191, 114). En estos casos, las dos primeras imágenes suscitan narraciones etiológicas. Respecto de la primera, explica por qué la estatua llevaba un curioso almirez sobre la cabeza de la diosa, en lugar de una corona, he aquí uno de los fragmentos conservados:

(...) Tú, cual a las orillas del Tritón de Asbista, tras afilar Hefesto el hacha para el parto, de la testa divina de tu padre saltaste ya con la armadura puesta (...) (1980: 154, 37).

En cuanto a la imagen de Hera, Calímaco trata el tema de la piel de león que se encontraba a los pies de la diosa además de un sarmiento:

A la Hera de Samos le trepa en derredor del pelo un sarmiento (ibid: 183, 101).

En cambio, la imagen del Apolo de Delos es ocasión para una composición del género de la écfrasis:

(...) Tú, el de angulosa figura, ¡salve!... en el pórtico... “Sí, de Delos”. “¿Tú acaso...?”. "Sí, lo juro por... mí mismo...” ...”Sí, de oro”... “_Acaso... un cinturón $<$ te? rodea $>$ por la mitad...?”. ...”¿En tu mano $<$ izquierda $>$, cintio, $<$ un arco $>1$ levas $<$ y en tu diestra $>$ a tus Gracias adorables?"... "Para $<$ apartar $>$ a los locos de su impía desmesura... y ofrecer... a los hombres bondadosos..." (ibid: 191, 114).

Los dos Filóstratos, el Viejo y el Joven, así como Calístrato, testimonian cómo la écfrasis había adquirido carta de presentación en la antigüedad, al punto de constituir el eje de algunas de sus obras. Filóstrato el Viejo introduce al lector a la pinacoteca napolitana para hacer una mezcla entre la descripción y la reflexión sobre el texto mítico, a manera de ilustración considérese lo que expone de un cuadro sobre Escamandro:

¿Te has fijado, muchacho, que el tema de esta pintura está basado en Homero o no te has dado cuenta considerando la maravilla de cómo es posible que el fuego viva dentro del agua? Veamos pues lo que significa. Observa este hecho, como si lo vieras en realidad fuera del cuadro. Seguramente conocer el pasaje de la Ilíada donde Homero hace que Aquiles se levante para vengar a Patroclo y los dioses se preparan para luchas unos con otros. De esta riña entre dioses el cuadro ignora otros detalles, pero 
cuenta que Hefesto, con gran violencia, se lanzó contra Escamandro. Ahora mira otra vez el cuadro: sigue a Homero en todo. (...) Las llamas del fuego no son ni rojizas ni tienen su aspecto usual, sino que resplandecen como el oro y como el sol. Pero esto ya no es de Homero... (1996: 225-226, I, 1-2).

En el texto corren paralelamente la descripción y la referencia literaria: ambas se complementan recíprocamente.

Si bien toda imagen siempre transmite, "dice" algo; también puede cumplir un papel narrativo, máxime en cierto tipo de composiciones. Tal es el caso del mural que se encuentra en la Basílica de Cartago, en Costa Rica, en donde se representa el hallazgo de la imagen de la Virgen de los Ángeles. En este sentido, al inicio del presente artículo se hizo referencia a numerosas representaciones en las basílicas europeas, muchas de las cuales constituyen secuencias narrativas en las que se muestra la historia del pueblo de Israel, por ejemplo.

Desde un punto de vista retórico, en no pocas obras la descripción de una imagen sirve como introducción a un problema o a la narración. En la Tabla de Cebes, es el preludio a un discurso de corte moral, el cual tiene lugar al explicarse su significado. El texto inicia así:

Paseábamos casualmente por el recinto sagrado de Crono, ${ }^{\mathrm{I}}$ en donde veíamos muchas y muy diversas ofrendas; $y$ entre ellas se alzaba una tabla frente al santuario en la que había una extraña pintura con curiosas escenas que no éramos capa- ${ }^{2}$ ces de interpretar qué eran ni de cuándo databan; pues lo pintado no nos parecía que fuera una ciudad ni un ejército, sino que era un recinto que contenía otros dos recintos, uno mayor y otro menor. Había también una puerta en el primer recinto y junto a la puerta nos pareció que había una gran muchedumbre en pie, y dentro del recinto se veía una multitud de mujeres. ${ }^{3}$
Junto a la entrada de la primera puerta y el primer recinto un anciano que estaba en pie se dirigía con énfasis a la multitud que entreba como si les estuviera dando alguna orden.

Tras estar mucho tiempo perplejos sobre la interpretación II

de la tabla, se presentó un anciano, y dijo:

-No es raro, extranjeros, que os quedéis

perplejos ante esta tabla, pues ni siquiera

muchos de los lugareños saben qué

puede significar la escena, y es que

no es una ofrenda de la ${ }^{2}$ ciudad, sino que en

cierta ocasión, hace mucho tiempo, vino

aquí un extranjero, varón prudente y

extraordinariamente sabio, seguidor de palabra y de obra de un género de vida pitagórico y parmenídeo, el cual consagró a Crono este recinto sagrado y la tabla (Epicteto 1995: 23-25).

Seguidamente, el anciano empieza a exponer el sentido del cuadro:

-Que si prestáis atención -dijoy comprendéis lo que se dice, seréis sensatos y felices, y si no, os volveréis insensatos, infelices, crueles, ignorantes y llevaréis una mala vida.

Pues la explicación es semejante al enigma que la Esfinge ${ }^{2}$

proponía a los humanos: si uno lo comprendía, se salvaba; pero si no lo comprendía, perecía a manos de la Esfinge. Y lo mismo sucede con esta explicación: pues la insensatez es para

los hombres una Esfinge. El enigma que nos propone es el ${ }^{3}$

siguiente: qué es lo bueno y qué es lo malo en la vida, y qué

no es ni bueno ni malo en la vida (Ibid).

Una última particularidad de texto lo constituyen las llamadas metaimágenes (sobre el tema puede leerse Mitchell 2009: 39). Se trata de imágenes autorreferenciales, las cuales en el campo de la imagen religiosa podrían tener aplicación. En la literatura, la descripción de un 
cuadro de Narciso hecha por Filóstrato el Viejo es ejemplar en este ámbito:

La fuente dibuja la imagen de Narciso y el cuadro la fuente y todo lo referente a Narciso. Un muchacho que acaba de poner fin a su cacería está de pie junto a una fuente, arrastrado por el deseo de sí mismo y enamorado de su propia cara que, reluciente, se refleja, como ves, en el agua (1996: 261, I, 23, 1).

Si bien este cuadro no es de carácter religioso, si lo es mítico. Expone dos niveles de representación: primero, el de la escena de Narciso junto a la fuente; segundo, el de la fuente respecto de la figura de Narciso. El poeta es consciente de esta propiedad, y se ve seducido por ella, así que líneas más adelante jugará con las categorías de realidad que se involucran. Por el momento, continúa con los planos de representación:

Sin duda ésta es la cueva de Aqueloo y de las Ninfas; el cuadro lo representa con realismo: las estatuas de piedra están realizadas toscamente, como corresponde al tipo de piedra que allí se encuentra (ibid).

Nuevamente el cuadro, representación pictórica, incorpora dentro de sí elementos representativos como las estatuas. A diferencia de estas, la relación entre la imagen del cuadro y la de la fuente era más próxima, si se quiere, se basaba en una analogía más fuerte. En cambio, este vínculo en el caso de las estatuas aparece más débil.

Seguidamente, al referirse a las virtudes de la obra se indica:

Hasta tal punto el cuadro hace honor a la verdad que unas gotas de rocío lucen sobre los pétalos de las flores, y sobre ellas se ha posado una abeja, no sé si es una abeja de verdad engañada por el cuadro o una abeja pintada en él para engañarnos a nosotros; pero dejémoslo.

En cambio a ti, Narciso, ningún cuadro te ha engañado, ni has sido cautivado por unos colores o por la cera, al contrario, eres tú la imagen que modeló el agua, así tal como la has visto; sin embargo, no saber ver el artificio de la fuente, aunque solo tendrías que inclinarte o mover ligeramente el cuerpo o bajar la mano para comprobarlo, y no quedarte plantado siempre en la misma posición, como si, habiendo encontrado a un compañero, esperaras a que se moviera (1996: 261-262, I, 23, 2-3).

En la descripción se duda del status óntico de la abeja, la que, si fuera real, ha sido engañada por el cuadro, mas si es mera representación, se confunde con lo real. Esta exquisita digresión le permite reflexionar sobre la suerte de Narciso.

Tal problemática fue abordada expresamente por Filóstrato el Joven, quien al respecto indica:

Hay en la pintura un dulce engaño, en absoluto reprochable, ya que confrontar lo que no es con lo que es, dejarse influir por ello, como creyendo que sí es en realidad, sin hacer daño alguno, ¿acaso no es ésta una manera perfecta de seducir la atención? (1996: 334, Proemio 4).

Sobre la relación entre el arte de las imágenes y la escritura, este mismo autor indica:

Analizándolo bien, uno descubre que este arte tiene mucho que ver con la poesía pues ambos comparten la imaginación. Los poetas introducen a los dioses en su propia escena, como estando ahí, y los acompañan con cuantas cosas representan su majestad, venerabilidad y entretenimiento; la pintura igual: todo cuanto los poetas dicen con palabras, ésta lo indica gráficamente (ibid:6).

En otro ámbito de las artes plásticas, Calístrato trata de las problemáticas relaciones entre realidad y representación artística en sus Descripciones:

Era la estatua de una Bacante que, hecha con mármol de Paros, fue transformada en una Bacante de verdad. La piedra, aun reteniendo su propia textura, parecía ir más allá de las leyes que rigen a las piedras: pues era en realidad una imagen, pero el arte había confundido la representación con la realidad (1996: 369, 2.2).

Concluimos este apartado con una brillante síntesis de las relaciones existentes entre la retórica y las artes plásticas ofrecida por Luciano de Samosata, quien en su diálogo Los retratos expresaba a través de Licino, uno de los personajes:

Y aunque tenemos aquí que Eufranor y Apeles, hemos sacado a la luz a Homero, al mejor de los pintores (1988: 433, 43, 8). 
Con lo cual hacía eco de la comparación que Simónides ya había establecido entre la pintura y la poesía en la segunda sofística.

\section{Funciones de las imágenes míticas}

Se pueden identificar diez funciones principales de los íconos míticos:

1) una función ostensiva-representativa,

2) una función distintiva-identitaria,

3) una función didascálica,

4) una función mnemónica,

5) una función cohesionadora,

6) una función narrativa,

7) una función argumentativa,

8) una función dialógica,

9) una función inspiradora, y, por último

10) una función estética.

La función ostensiva permite que el mito, concepto de contenido abstracto y sobrenatural, se materialice ante los ojos del pueblo. De esta manera el mito, o una parte de él, se muestra al creyente como realidad concreta, se muestra como verosímil, es decir, aquello que es semejante a lo verdadero. Concurre con el papel ostensivo el representativo, pues la imagen, merced a que representa ya a la divinidad, ya al espíritu, ya al héroe... lo muestra.

Esta función integra de alguna manera las propiedades denotativa y connotativa que Barthes identifica en las imágenes publicitarias. La primera, es decir, la denotativa, corresponden a la mera descripción de la imagen; la segunda, la denotativa, comprende el cúmulo de asociaciones, símbolos y aspectos culturales a que la imagen alude.

Es en el ámbito de la connotación donde destaca el carácter ideológico de la imagen, máxime el de la imagen mítica. Sus significantes, que Barthes llama connotadores, constituyen en el sistema por él propuesto la retórica, entendida como la parte significante de la ideología (1977: 49).
En el ámbito social, por su parte, las imágenes permiten identificar al grupo: así las católicos poseen sus símbolos particulares (escapularios, crucifijos...), los hindúes los propios y así muchas otras culturas.

Los íconos también, gracias a que transmiten información, transmiten conocimiento sobre los mitos a que se refieran. De ahí que se pueda hablar de una función didascálica, pues educan, tanto en comunidades analfabetas como las letradas.

Este carácter didascálico consiste en la transmisión del contenido del mito a las generaciones futuras a través de los sentidos: la vista, en primer lugar, sin descartar el olfato, el tacto, el oído, el gusto, en particular asociados se experiencias de carácter ritual.

Por esto es comprensible que la imagen trae y fija en la memoria un contenido de naturaleza mítica, con lo que contribuye a la perpetuación de las creencias, de lo cual se desprende su función mnemónica, debido a que la imagen representa al mito o una de sus partes: para quien lo conoce, no solo transmite información, sino que recuerda y refuerza el conocimiento adquirido. Además, no pocos devotos gustan tener una imagen consigo como apoyo en los momentos difíciles de la vida.

Nuevamente en el plano social, muchas imágenes están asociadas a rituales en los que sirven de centro o foco de reunión. Ya sea en estas celebraciones o fuera de ellas, las imágenes logran reforzar la comunión entre los miembros del grupo.

Como supra se señaló, toda imagen "dice" algo, y muchas, en realidad, contienen verdaderas narraciones míticas.

Deriva de la primera función su carácter argumentativo: en especial, el exemplum. A través de esta (de)mostración del mito se corroboran las características y el contenido esencial del mito. Las propiedades de la divinidad son reproducidas en la imagen, la escultura, y corroboran lo que por el oído se había adquirido en un inicio. La imagen es una prueba de orden "testimonial", en la que el observador se convierte en testigo de la verdad, de la tradición, transmitidas. 
La pluralidad de tesis relativas a una imagen es tan diversa como en el plano conversacional: en primera instancia, se tiene la veracidad del mito, en segundo, sus implicaciones. Por ejemplo, una escultura que presente a san Francisco de Asís amoroso con los animales, a san Miguel Comboni auxiliando a un pequeño africano, bien pueden despertar vocaciones que imiten la vida y acciones de los fundadores. Otra imagen podría mostrar al santo Cura de Ars administrando el sacramento de la confesión para que hagan a un lado su reticencia a confesarse.

El carácter dialógico hace referencia a que la imagen permite al ser humano establecer un diálogo directo con lo que concibe como el mundo de lo divino. Al ser un referente en el espacio, como cualquier interlocutor, permite constituir un verdadero y real diálogo, sin menoscabo de otras formas de comunicación de los creyentes con la divinidad.

Las dos últimas funciones, por su parte, se encuentran estrechamente unidas, dado que aluden al cúmulo de emociones y sensaciones que suscita la contemplación de una imagen. Por un lado, estas emociones pueden suscitar actitudes, comportamientos o pensamientos, por ejemplo, la contrición por los pecados, la conversión de vida, el espíritu de caridad, el inicio de una empresa religiosa...

Por otro lado, se tiene el valor estético de la imagen, aquella faceta que despertará particularmente un cúmulo de emociones (pathos) que interactuarán dialécticamente con el logos y el ethos.

\section{El ethos}

Grosso modo el logos y el pathos, principales pruebas aristotélicas, líneas atrás han sido consideradas en relación con las imágenes míticas. Resta ahora atender al ethos, al respecto expresa Aristóteles:

Pues bien, <se persuade> por el talante (éthos), cuando el discurso es dicho de tal forma que hace al orador digno de crédito. Porque a las personas honradas las creemos más y con mayor rapidez, en general en todas las cosas, pero, desde luego, completamente en aquéllas en que no cabe la exactitud, sino que se prestan a duda; si bien es preciso que también esto acontezca por obra del discurso y no por tener prejuzgado cómo es el que habla. Por lo tanto, no <es cierto que $>$, en el arte, como afirman algunos tratadistas, la honradez del que habla no incorpore nada en orden a lo convincente, sino que, por así decirlo, casi es el talante personal quien constituye el más firme $<$ medio de> persuasión (1999: 1356a5-15, 176, ni el paréntesis ni la itálica están en el original).

Ahora bien, el primer problema que plantea esta prueba en esta materia es determinar quién es el emisor, el orador, respecto de una imagen, ¿acaso es el artista? pero, si no es él, ¿quién?

Si bien el artista puede concebirse como un emisor-orador, por la naturaleza del mito, el verdadero emisor, es decir, aquel que tiene vocación de credibilidad es la institución, el sistema de creencias, quien se propone como emisor-orador digno de credibilidad en relación con el discurso mítico, respecto de cuyo sistema la imagen forma una parte. De esta manera, la imagen de alguna manera otorga algún grado de credibilidad al colectivo social en el cual se integra y es interpretada.

\section{Bibliografía}

Aristóteles. (1990). Retórica. $2^{\mathrm{a}}$ reimpresión. Editorial Gredos, S. A. Madrid.

Barthes, Roland. (1977). Rhetoric of image. En Image, music, text. Essays selected and translated by Stephen Heat. Hill and Wang. p. 33-55.

Bauzá, Hugo Francisco. (2004). El mundo del mito. En El imaginario en el mito clásico. IV Jornada organizada por el "Centro de Estudios del Imaginario". Hugo Francisco Bauzá (compilador). Academia Nacional de Ciencias de Buenos Aires. Buenos Aires. 
Calímaco. (1980). Himnos, epigramas y fragmentos. $2^{\mathrm{a}}$ reimpresión. Editorial Gredos, S. A. Madrid.

Epicteto, Cayo Mausonio Rufo. (1995). Tabla de Cebes; Disertaciones; Fragmentos menores; Manual; Fragmentos. Introducciones, traducción y notas de Paloma Ortiz García. Editorial Gredos, Madrid.

Filóstrato, Calístrato. (1996). Heroico Gimnástico - Descripciones de Cuadros - Descripciones. Introducción de Carlos Miralles. Traducción y notas de Francesca Mestre. Editorial Gredos, Madrid.

Gill, Ann M. y Whedbee, Karen. (2003). Retórica. En van Dijk, Teun A. (compilador), El discurso como estructura y proceso. $2^{\mathrm{a}}$ reimpresión. Editorial Gedisa, S. A. Barcelon.

Hesíodo. (2000). Teogonía, Trabajos y Días, Escudo, Certamen. Alianza Editorial, S. A. Madrid.

Luciano. (1988). Obras II. 1 $1^{\mathrm{a}}$ edición. Editorial Gredos, S. A., Madrid.

Mitchell, W. J. T. (2009). Teoría de la imagen. $1^{a}$ edición. Ediciones Akal, S. A. Madrid.

Panofsky, Erwin. (1979). Estudios sobre iconología. $3^{\text {a }}$ edición. Alianza Editorial, S. A. Madrid.

Real Academia de la Lengua Española. (2001). Diccionario de la lengua española. Tomo II. $22^{\text {a }}$ edición. Espasa Calpe, S. A. Madrid. 
